\title{
The Varicella-Zoster Virus Genome
}

\author{
Jeffrey I. Cohen, M.D. \\ Laboratory of Clinical Infectious Diseases, Bldg. 10, Room 11N234, National Institutes of Health, \\ 10 Center Drive, Bethesda, MD 20892
}

\begin{abstract}
The varicella-zoster virus (VZV) genome contains at least 70 genes, and all but 6 have homologs in herpes simplex virus. Cosmids and BACs corresponding to the VZV parental Oka and vaccine Oka viruses have been used to "knock-out" 34 VZV genes. Seven VZV genes (ORF4, 5, 9, 21, 29, 62 , and 68) have been shown to be required for growth in vitro. Recombinant viruses expressing several markers (e.g. beta-galactosidase, green fluorescence protein, luciferase) and several foreign viral genes (from herpes simplex, Epstein-Barr virus, hepatitis B, mumps, HIV and simian immunodeficiency virus) have been constructed. Further studies of the VZV genome, using recombinant viruses, may facilitate the development of safer and more effective VZV vaccines. Furthermore, VZV might be useful as a vaccine vector to immunize against both VZV and other viruses.
\end{abstract}

\section{Genome Structure and Organization}

Varicella-zoster virus (VZV) is an alphaherpesvirus that is in the same subfamily as herpes simplex virus (HSV) 1 and 2 . VZV is a member of varicellovirus genus, along with equine herpesvirus 1 and 4, pseudorabies virus, and bovine herpesvirus 1 and 5. Ceropithecine herpesvirus 9 (simian varicella virus) is virus most homologous to VZV.

\subsection{VZV genome}

The complete sequence of the VZV genome was determined by Davison and Scott (1986). The prototype strain, VZV Dumas is 124,884 base pairs in length. The genome consists of a unique long region (UL) bounded by terminal long (TRL) and internal long (IRL) repeats, and a unique short region (US) bounded by internal short (IRS), and terminal short (TRS) repeats (Figure 1). The US region can orientate either of two directions, while the UL region rarely changes its orientation; thus, there are usually two isomers of the genome in infected cells. The genome is linear in virions with an unpaired nucleotide at each end. In VZVinfected cells the ends pair and the genome circularizes.

The genome has five repeat regions. Repeat region 1 (R1) is located in open reading frame (ORF) 11, R2 is located in ORF14 (glycoprotein C), R3 in ORF22, R4 between ORF62 and the origin of viral replication, and R5 between ORF 60 and 61 . The length of the repeat regions varies among different VZV strains and has been used to distinguish the strains.

\subsection{VZV genes}

1.2.1 VZV immediate-early genes-VZV encodes at least 70 genes, three (ORF62, 63, 64) are which are present in both of the short repeat regions (Cohen et al. 2007b). VZV encodes at least 3 immediate-early (IE) proteins that are located in the tegument of virions and regulate virus transcription (Table 1). IE4 and IE62 transactivate IE, late, and early 
promoters. IE63 represses several VZV promoters, and inhibits the activity of interferonalpha (Ambagala et al. 2007), and binds to anti-silencing protein 1 (Ambagala et al. 2009). ORF61 protein, which is not present in the tegument of virions and has not been shown to be an IE gene, activates IE, early, and late viral promoters.

1.2.2 VZV genes encoding replication proteins-VZV encodes a viral DNA polymerase, likely composed of two subunits (ORF28 and ORF16) that is inhibited by acyclovir. The viral thymidine kinase (ORF36) phosphorylates deoxycytidine, thymidine, and acyclovir. VZV ORF18 and ORF19 encode the small and large subunits of ribonucleotide reductase which convert ribonucleotides to deoxyribonucleotides. VZV encodes at least two DNA binding proteins- ORF29 protein is a single-stranded DNA binding protein, and ORF 51 protein binds to the origin of DNA replication. VZV encodes two protein kinases. ORF47 protein phosphorylates VZV ORF32 protein, IE62, IE63, and glycoprotein I. ORF66 protein phosphorylates IE62 which results inclusion of IE62 into the virion tegument. VZV encodes other enzymes including a dUTPase (ORF8), thymidylate synthetase (ORF13), protease (ORF33), DNase (ORF48), and uracil DNA glycosylase (ORF59).

1.2.3 VZV genes encoding putative late proteins-VZV ORF10 encodes a tegument protein that forms a complex with transcription factors at the ORF62 promoter to activate transcription of ORF62. ORF17 protein induces cleavage of RNA. ORF33.5 encodes the assembly protein which forms a scaffold thought be involved in construction of nucleocapsids. ORF40 encodes the major nucleocapsid protein, while ORF21 also encodes a nucleocapsid protein. ORF54 encodes the putative portal protein which allows viral DNA to enter nucleocapsids.

1.2.4 VZV genes encoding glycoproteins-VZV encodes 7 viral glycoproteins- $\mathrm{gB}$ (ORF31), gC (ORF14), gE (OEF68), gH (ORF 37), gI (ORF67), gK (ORF 5), gL (ORF 60), gM (ORF50), and presumably gN (ORF9A). VZV gB, based on homology with $\mathrm{HSV}$ gB, is likely critical for entry of virus into cells. $\mathrm{gE}$ is binds to a cellular receptor (insulin degrading enzyme [Li et al. 2006]) and $\mathrm{gH}$ and $\mathrm{gM}$ are important for cell-to-cell spread of virus (Yamagishi et al. 2008). $\mathrm{gI}$ facilitates maturation of $\mathrm{gE}$, and $\mathrm{gL}$ is a chaperone for $\mathrm{gH}$. gK may be important for syncytia formation.

\section{Comparative genomics of VZV and HSV}

VZV and HSV are largely collinear, although the UL region of HSV is orientated in the opposite direction to that of VZV using the standard nomenclature. The VZV US region is much shorter $(5.2 \mathrm{~kb})$ than HSV-1 US $(13.0 \mathrm{~kb})$ and the VZV TRL and IRL regions are also shorter $(0.9 \mathrm{~kb})$ than their HSV-1 counterparts $(9.2 \mathrm{~kb})$.

\subsection{Core proteins conserved with herpesviruses in other subfamilies}

The VZV genome contains about 41 "core genes" that are conserved with each of the three subfamilies of herpesviruses, alphaherpesvirus, betaherpesvirus, and gammaherpesvirus (Davison 1993). Core genes include IE4, the VZV DNA polymerase, helicase-primase components, single-stranded DNA-binding protein, ribonucleotide reductase, uracil-DNA glycosylase, dUTPase, DNase, ORF47 protein kinase, major capsid protein, protease, assembly protein, several tegument proteins, $\mathrm{gB}, \mathrm{gH}, \mathrm{gL}, \mathrm{gM}$, and $\mathrm{gN}$.

\subsection{VZV functional and nonfunctional homologs of HSV genes}

Several VZV genes can complement their HSV homologs. VZV ORF61 can substitute for HSV ICP0 (Moriuchi et al. 1992) and VZV ORF62 can complement HSV ICP0 (Felser et al. 
1988). Although VZV ORF10 can complement the transactivating function of HSV VP16, HSV-1 VP16 is essential for replication of HSV while VZV ORF10 is dispensable (Cohen and Seidel 1994b; Moriuchi et al. 1993). VZV ORF 51 can complement HSV UL9 (Chen et al 1995). In contrast, VZV ORF4 cannot complement HSV ICP27 (Moriuchi et al 1994a).

\subsection{VZV genes not conserved with HSV}

VZV encodes 6 genes (ORF1,2,13,32,57, and S/L) that are absent in HSV (Figure 1). ORF 13 encodes the viral thymidylate synthetase which has a homolog in herpesvirus saimiri and Kaposi's sarcoma associated herpesvirus.

\subsection{HSV genes not conserved with VZV}

HSV encodes 9 genes (UL45, UL56, US2, US5, US6, US11, US12, and LAT) that are absent in VZV (Figure 1). HSV US 12 encodes ICP47, which blocks presentation of MHC class I. HSV US6, US 4, and US5 encode glycoproteins D, G, and J, respectively. VZV gE is the most abundant viral glycoprotein and shares many features of $\mathrm{HSV} g D$, including binding to a cellular receptor which contributes to VZV entry (Li et al. 2007).

\section{Mutagenesis with cosmids and BACs}

\subsection{Mutagenesis using marker rescue}

The first genetically engineered mutant of VZV was constructed in 1987 in which the Epstein-Barr virus gp350 gene was inserted into the VZV genome (Lowe et al. 1987). Fibroblasts were cotransfected with VZV viron DNA and a plasmid with EBV gp350 flanked by VZV thymidine kinase sequences and plaques were purified by limiting dilution. While the procedure was successful, the process of plaque purification which requires sequential rounds of sonication is very labor intensive. The same strategy in which VZV virion DNA is contransfected with plasmids with flanking sequences that are homologous to VZV DNA was used to reinsert and thereby "rescue" essential genes into the genome of VZV lacking ORF4 (Cohen et al.. 2005), ORF21 (Xia et al. 2003), and ORF68 (Ali et al. 2009).

\subsection{Mutagenesis using cosmids}

A cosmid system was first used to generate mutations in the VZV genome in 1993 (Cohen and Seidel 1993). Virion DNA was isolated from the Oka vaccine strain of VZV, the linear DNA was blunted with T4 DNA polymerase, and oligonucleotides containing Not I or Mst II restriction sites were ligated to the DNA. The resulting DNA was cut with Mst II or Not I and four large DNA fragments, which overlap the entire VZV genome were ligated into a cosmid vector that was linearized with Mst II or Not I. Human melanoma cells were transfected with the four cosmids along with a plasmid encoding VZV IE62 which increases the infectivity of viral DNA (Moriuchi et al 1994b). While the cosmids are able to produce infectious virus in the absence of the plasmid, the latter increases the reliability and enhances the efficiency of virus production. Recombinant VZV derived from the cosmids grew to similar titers as the nonrecombinant virus used to generate the cosmids.

Other cosmid systems have also developed to perform VZV mutagenesis. Mallory et al. (1997) used 5 cosmids derived from the Oka vaccine strain to produce recombinant virus and Niizuma et al. (2003) described a cosmid library from the parental Oka vaccine. These cosmids have been used to "knock-out" a large number of VZV genes and to study the phenotype of the resulting mutants in cell culture and rodents. 


\subsection{Mutagenesis using BACs}

Four separate BACs have been constructed for VZV mutagenesis. Three research groups have inserted the parental Oka virus into BACs (Nagaike et al. 2004; Zhang et al. 2007; Tischer et al. 2007) and one group inserted the vaccine Oka virus into a BAC (Yoshii et al. 2007). While each of the recombinant parental Oka viruses derived from BACs grew to titers similar to nonrecombinant parental Oka virus, recombinant virus derived from the vaccine Oka BAC grew to slightly lower titers than the nonrecombinant vaccine Oka virus.

\subsection{Results of mutagenesis studies}

VZV cosmids and BACs have been used to mutate multiple VZV genes (Table 2). Several VZV genes (ORF4, 5, 9, 21, 29, 62, and 68) have been shown to be essential for replication in cells in vitro. Other VZV genes that have been tested are not required for growth in cell culture, but some are required for growth in certain types of cells in vitro (Cohen and Nguygen 1997), in lymphocytes (Moffat et al. 1998; Song et al. 2000), or in human skin (Moffat et al. 1998, and Chapter 12). Each of the 6 VZV genes which do not have HSV homologs (ORF1, 2, 13, 32, 57, and S/L) are not required for growth in cell culture (Cohen and Seidel 1995; Cohen and Seidel 1993; Cox et al. 1998; Reddy et al. 1998a; Sato et al. 2002b; Zhang et al. 2007).

Chimeras have been constructed containing various portions of the parental and vaccine Oka genomes (Zerboni et al. 2005). These chimeras have demonstrated that attenuation of VZV is a multigenic trait due to mutations throughout the genome.

VZV cosmids has been used to prove that mutations in individual genes correspond with resistance to antiviral compounds. Mutagenesis of VZV ORF54 (homologous to the portal protein of HSV) conferred resistance to a thioruea inhibitor compound (Visalli et al. 2003). VZV cosmids have been used to produce virus expressing beta-galactosidase (Cohen et al. 1998), green fluorescence protein (Zerboni et al. 2000, Li et al. 2006), or luciferase (Oliver et al. 2008, Zhang et al. 2007) which have been useful for studies in animals and virus entry in vitro.

Most recombinant viruses have stable genomes with a few exceptions. Attempts to delete or mutate one copy of a gene that is normally present in both of the short repeat regions of the genome often result in recombination with wild-type sequences in both short repeat regions after several rounds of replication (Sommer et al. 2001; Sato et al. 2003a; Oliver et al. 2008). In addition, point mutations that severely impair growth of the virus can sometimes undergo back mutation with reversion to wild-type virus over time (Cohen et al. 1998)

VZV genes thought to be required for cell growth have been proven to essential by growing a virus mutant unable to express the protein in a complementing cell line (Xia et al. 2003) or in cells infected with baculovirus expressing the VZV protein (Ali et al. 2009; Cohen et al. 2005; Cohen et al 2007) and then showing that the virus cannot be grown on noncomplementing cells. An alternative approach has been to insert the essential gene elsewhere in the viral genome. This latter method is not ideal, since the gene will not be formally proven to be required for growth. Inefficiency in cosmid transfections or impaired virus growth may be misinterpreted as showing that a virus gene is essential. One VZV gene, ORF63, has been reported to be essential in the absence of a complementation system (Sommer et al 2001), but was actually shown to be non-essential for growth in cell culture (Cohen et al. 2004). The failure to obtain virus in the former study may have been due to the lack of a cotransfected plasmid expressing the VZV IE62 gene to transiently enhance virus growth after cosmid DNA transfection (Baiker et al. 2004). 


\subsection{VZV as an expression vector}

VZV has been used to express a number of foreign viral proteins (Table 3). While these recombinant VZV mutants have been shown to induce immunity to the foreign virus and to protect animals from disease after challenging with the foreign virus in some cases (Heineman et al. 1995; Heineman et al. 2004), in one case the recombinant VZV actually enhanced replication of the foreign virus (Strapans et al. 2004). Thus, it is critical to test such recombinant viruses in animal models whenever possible. Since children are vaccinated with the varicella vaccine to prevent chickenpox, expression of additional viral proteins might allow immunization against other viruses and ultimately reduce the number of vaccines required during childhood.

\subsection{Use of genetics to develop safer VZV vaccines}

The current vaccine is very safe in immunocompetant persons, but it has caused disease in severely immunocompromised persons. Replication-defective vaccines might be developed by growing viruses in complementing cells; however, attempts to produce high titers of cellfree virus using this approach has been unsuccessful (Cohen, unpublished data). An alternative approach is to express an essential gene, such as one expressed during latency, under a different promoter, which may allow high titers of virus during replication, but may impair latency (Cohen et al 2007).

\section{Acknowledgments}

I thank the intramural research program of the National Institutes of Allergy and Infectious Diseases for support.

\section{Abbreviations}

$\begin{array}{ll}\text { VZV } & \text { varicella-zoster virus } \\ \text { HSV } & \text { herpes simplex virus } \\ \text { UL } & \text { unique long } \\ \text { TRL } & \text { terminal repeat long } \\ \text { IRL } & \text { internal repeat long } \\ \text { US } & \text { unique short } \\ \text { IRS } & \text { internal repeat short } \\ \text { TRS } & \text { terminal repeat short } \\ \text { IE } & \text { immediate-early }\end{array}$

\section{References}

Ali MA, Li Q, Fischer ER, Cohen JI. The insulin degrading enzyme binding domain of varicella-zoster virus (VZV) glycoprotein E is important for cell-to-cell spread and VZV infectivity, while a glycoprotein I binding domain is essential for infection. Virology. 2009; 386:270-279. [PubMed: 19233447]

Ambagala AP, Bosma T, Ali MA, Poustovoitov M, Chen JJ, Gershon MD, Adams PD, Cohen JI. Varicella-zoster virus immediate-early 63 protein interacts with human antisilencing function 1 protein and alters its ability to bind histones H3.1 and H3.3. J Virol. 2009; 83:200-209. [PubMed: 18971269]

Ambagala AP, Cohen JI. Varicella-Zoster virus IE63, a major viral latency protein, is required to inhibit the alpha interferon-induced antiviral response. J Virol. 2007; 81:7844-7851. [PubMed: 17507475] 
Baiker A, Bagowski C, Ito H, Sommer M, Zerboni L, Fabel K, Hay J, Ruyechan W, Arvin AM. The immediate-early 63 protein of varicella-zoster virus: analysis of functional domains required for replication in vitro and for T-cell and skin tropism in the SCIDhu model in vivo. J Virol. 2004; 78:1181-1194. [PubMed: 14722273]

Chaudhuri V, Sommer M, Rajamani J, Zerboni L, Arvin AM. Functions of Varicella-zoster virus ORF23 capsid protein in viral replication and the pathogenesis of skin infection. J Virol. 2008; 82:10231-10246. [PubMed: 18684828]

Che X, Reichelt M, Sommer MH, Rajamani J, Zerboni L, Arvin AM. Functions of the ORF9-toORF12 gene cluster in varicella-zoster virus replication and in the pathogenesis of skin infection. $\mathrm{J}$ Virol. 2008; 82:5825-5834. [PubMed: 18400847]

Chen D, Stabell EC, Olivio PD. Varicella-zoster virus gene 51 complements a herpes simplex virus type I UL9 mutant. J Virol. 1995; 69:4515-4518. [PubMed: 7769714]

Cohen JI. Genomic structure and organization of varicella zoster virus. Contrib Microbiol. 1999; 3:1020. [PubMed: 10599518]

Cohen JI, Cox E, Pesnicak L, Srinivas S, Krogmann T. The varicella-zoster virus ORF63 latencyassociated protein is critical for establishment of latency. J Virol. 2004; 78:1833-11840.

Cohen JI, Krogmann T, Pesnicak L, Ali MA. Absence or overexpression of the varicella-zoster virus (VZV) ORF29 latency-associated protein impairs late gene expression and reduces latency in a rodent model. J Virol. 2007a; 81:1586-1591. [PubMed: 17151102]

Cohen JI, Krogmann T, Ross JP, Pesnicak LP, Prikhod ko EA. The varicella-zoster virus ORF4 latency associated protein is important for establishment of latency. J Virol. 2005; 79:6969-6975. [PubMed: 15890936]

Cohen JI, Nguyen H. Varicella-zoster virus glycoprotein I (gI) is essential for growth of virus in Vero cells. J Virol. 1997; 71:6913-6920. [PubMed: 9261418]

Cohen JI, Nguyen H. Varicella-zoster virus ORF61 deletion mutants replicate in cell culture, but a mutant with stop codons in ORF61 reverts to wild-type virus. Virology. 1998; 246:306-316. [PubMed: 9657949]

Cohen JI, Seidel KE. Generation of varicella-zoster virus (VZV) and viral mutants from cosmid DNAs: VZV thymidylate synthetase is not essential for replication in vitro. Proc Natl Acad Sci USA. 1993; 90:7376-7380. [PubMed: 8394020]

Cohen JI, Seidel KE. Absence of varicella-zoster virus (VZV) glycoprotein V does not alter growth of VZV in vitro or sensitivity to heparin. J Gen Virol. 1994a; 75:3087-3093. [PubMed: 7964618]

Cohen JI, Seidel KE. Varicella-zoster virus (VZV) open reading frame 10 protein, the homolog of the essential herpes simplex virus protein VP16, is dispensable for VZV replication in vitro. J Virol. 1994b; 68:7850-7858. [PubMed: 7966575]

Cohen JI, Seidel KE. Varicella-zoster virus open reading frame 1 encodes a membrane protein that is dispensable for growth of VZV in vitro. Virology. 1995; 206:835-842. [PubMed: 7856096]

Cohen JI, Sato H, Srinivas S, Lekstrom K. The varicella-zoster virus (VZV) ORF65 virion protein is dispensable for replication in cell culture and is phosphorylated by casein kinase II, but not by the VZV protein kinases. Virology. 2001; 280:62-71. [PubMed: 11162819]

Cohen, JI.; Straus, SE.; Arvin, AM. Varicella-zoster virus: Replication, pathogenesis, and management. In: Knipe, DM.; Howley, PM., editors. Fields Virology. 5th ed.. Philadelphia: Lippincott-Williams \& Wilkins; 2007 b.

Cohen JI, Wang Y, Nussenblatt R, Straus SE, Hooks JJ. Chronic uveitis in guinea pigs infected with varicella-zoster virus expressing Escherichia coli beta-galactosidase. J Infect Dis. 1998; 177:293300. [PubMed: 9466514]

Cox E, Reddy S, Iofin I, Cohen J. Varicella-zoster virus ORF57, unlike its pseudorabies virus UL3.5 homolog, is dispensable for replication in cell culture. Virology. 1998; 250:205-209. [PubMed: 9770434]

Davison AJ. Herpesvirus genes. Rev Med Virol. 1993; 3:237-244.

Davison AJ, Scott J. The complete DNA sequence of varicella-zoster virus. J Gen Virol. 1986; 67:1759-1816. [PubMed: 3018124] 
Felser JM, Kinchington PR, Inchauspe G, Straus SE, Ostrove JM. Cell lines containing varicella-zoster virus open reading frame 62 and expressing the "IE" 175 protein complement ICP4 mutants of herpes simplex virus type 1. J Virol. 1988; 62:2076-2082. [PubMed: 2835512]

Heineman TC, Cohen JI. Deletion of the varicella-zoster virus large subunit of ribonucleotide reductase impairs the growth of virus in vitro. J. Virol. 1994; 68:3317-3323. [PubMed: 8151792]

Heineman TC, Cohen JI. The varicella-zoster virus (VZV) open reading frame 47 (ORF47) protein kinase is dispensable for viral replication and is not required for phosphorylation of ORF63 protein, the VZV homolog of herpes simplex virus ICP22. J Virol. 1995; 69:7367-7370. [PubMed: 7474171]

Heineman TC, Connelly BL, Bourne N, Stanberry LR, Cohen JI. Immunization with recombinant varicella-zoster virus expressing herpes simplex virus type 2 glycoprotein $D$ reduces the severity of genital herpes in guinea pigs. J Virol. 1995; 69:8109-8113. [PubMed: 7494331]

Heineman TC, Seidel K, Cohen JI. The varicella-zoster virus ORF66 protein induces kinase activity and is dispensable for viral replication. J Virol. 1996; 70:7312-7317. [PubMed: 8794389]

Heineman T, Pesnicak L, Ali M, Krogmann T, Krudwig N, Cohen JI. Varicella-zoster virus expressing HSV-2 glycoproteins B and D induces protection against HSV-2 challenge. Vaccine. 2004; 22:2558-2565. [PubMed: 15193381]

Ito H, Sommer MH, Zerboni L, Baiker A, Sato B, Liang R, Hay J, Ruyechan W, Arvin AM. Role of the varicella-zoster virus gene product encoded by open reading frame 35 in viral replication in vitro and in differentiated human skin and T cells in vivo. J Virol. 2005; 79:4819-4827. [PubMed: 15795267]

Li Q, Ali MA, Cohen JI. Insulin degrading enzyme is a cellular receptor for varicella-zoster virus infection and for cell-to-cell spread of virus. Cell. 2006; 127:305-316. [PubMed: 17055432]

Lowe RS, Keller PM, Keech BJ, Davison AJ, Whang Y, Morgan AJ, Kieff E, Ellis RW. Varicellazoster virus as a live vector for the expression of foreign genes. Proc Natl Acad Sci U S A. 1987; 84:3896-3900. [PubMed: 3035557]

Mallory S, Sommer M, Arvin AM. Mutational analysis of the role of glycoprotein I in varicella-zoster virus replication and its effects on glycoprotein E conformation and trafficking. J Virol. 1997; 71:8279-8288. [PubMed: 9343180]

Mo C, Suen J, Sommer M, Arvin A. Characterization of Varicella-Zoster virus glycoprotein K (open reading frame 5) and its role in virus growth. J Virol. 1999; 73:4197-4207. [PubMed: 10196316]

Moffat JF, Zerboni L, Sommer MH, Heineman TC, Cohen JI, Kaneshima H, Arvin AM. The ORF47 and ORF66 putative protein kinases of varicella-zoster virus determine tropism for human T cells and skin in the SCID-hu mouse. Proc Natl Acad Sci U S A. 1999; 95:11969-11974. [PubMed: 9751774]

Moriuchi H, Moriuchi M, Smith HA, Cohen JI. Varicella-zoster virus open reading frame 4 protein is functionally distinct from and does not complement its herpes simplex virus type 1 homolog ICP27. J Virol. 1994a; 68:1987-1992. [PubMed: 8107260]

Moriuchi H, Moriuchi M, Smith HA, Straus SE, Cohen JI. Varicella-zoster virus open reading frame 61 protein is functionally homologous to herpes simplex virus type 1 ICP0. J Virol. 1992; 66:7303-7308. [PubMed: 1366099]

Moriuchi H, Moriuchi M, Straus SE, Cohen JI. Varicella-zoster virus open reading frame 10 protein, the herpes simplex virus VP16 homolog, transactivates herpesvirus immediate-early gene promoters. J Virol. 1993; 67:2739-2746. [PubMed: 8386275]

Moriuchi M, Moriuchi H, Straus SE, Cohen JI. Varicella-zoster virus (VZV) virion-associated transactivator open reading frame 62 protein enhances the infectivity of VZV DNA. Virology. 1994b; 200:297-300. [PubMed: 8128631]

Nagaike K, Mori Y, Gomi Y, Yoshii H, Takahashi M, Wagner M, Koszinowski U, Yamanishi K. Cloning of the varicella-zoster virus genome as an infectious bacterial artificial chromosome in Escherichia coli Vaccine. 2004; 22:4069-4074.

Niizuma T, Zerboni L, Sommer MH, Ito H, Hinchliffe S, Arvin AM. Construction of varicella-zoster virus recombinants from parent Oka cosmids and demonstration that ORF65 protein is dispensable for infection of human skin and T cells in the SCID-hu mouse model. J Virol. 2003; 77:60626065. [PubMed: 12719598] 
Oliver SL, Zerboni L, Sommer M, Rajamani J, Arvin AM. Development of recombinant varicellazoster viruses expressing luciferase fusion proteins for live in vivo imaging in human skin and dorsal root ganglia xenografts. J Virol Methods. 2008; 154:182-193. [PubMed: 18761377]

Reddy SM, Cox E, Iofin I, Soong W, Cohen JI. Varicella-zoster virus (VZV) ORF32 encodes a phosphoprotein that is posttranscriptionally modified by the VZV ORF47 protein kinase. J Virol. 1998a; 72:8083-8088. [PubMed: 9733848]

Reddy SM, Williams M, Cohen JI. Expression of a uracil DNA glycosylase (UNG) inhibitor in mammalian cells: varicella-zoster virus can replicate in vitro in the absence of detectable UNG activity. Virology. 1998b; 251:393-401. [PubMed: 9837803]

Ross J, Williams M, Cohen JI. Disruption of the varicella-zoster virus dUTPase and the adjacent ORF9A gene results in impaired growth and reduced syncytia formation in vitro. Virology. 1997; 234:186-195. [PubMed: 9268149]

Sadaoka T, Yoshii H, Imazawa T, Yamanishi K, Mori Y. Deletion in open reading frame 49 of varicella-zoster virus reduces virus growth in human malignant melanoma cells but not in human embryonic fibroblasts. J Virol. 2007; 81:12654-12665. [PubMed: 17855513]

Sato B, Ito H, Hinchliffe S, Sommer MH, Zerboni L, Arvin AM. Mutational analysis of open reading frames 62 and 71, encoding the varicella-zoster virus immediate-early transactivating protein, IE62, and effects on replication in vitro and in skin xenografts in the SCID-hu mouse in vivo. J Virol. 2003a; 77:5607-5620. [PubMed: 12719553]

Sato B, Sommer M, Ito H, Arvin AM. Requirement of varicella-zoster virus immediate-early 4 protein for viral replication. J Virol. 2003b; 7:12369-12372.

Sato H, Callanan LD, Pesnicak L, Krogmann T, Cohen JI. Varicella-zoster virus (VZV) ORF17 protein induces RNA cleavage and is critical for replication of VZV at $37^{\circ} \mathrm{C}$, but not $33^{\circ} \mathrm{C}$. $\mathrm{J}$ Virol. 2002a; 76:11012-11023. [PubMed: 12368344]

Sato H, Pesnicak L, Cohen JI. Varicella-zoster virus ORF2 encodes a membrane phosphoprotein that is dispensable for viral replication and for establishment of latency. J Virol. 2002b; 76:3575-3578. [PubMed: 11884583]

Shiraki K, Hayakawa Y, Mori H, Namazue J, Takamizawa A, Yoshida I, Yamanishi K, Takahashi M. Development of immunogenic recombinant Oka varicella vaccine expressing hepatitis B virus surface antigen. J Gen Virol. 1991; 72:1393-1399. [PubMed: 1646279]

Shiraki K, Sato H, Yoshida Y, Yamamura JI, Tsurita M, Kurokawa M, Kageyama S. Construction of Oka varicella vaccine expressing human immunodeficiency virus env antigen. J Med Virol. 2001; 64:89-95. [PubMed: 11360239]

Somboonthum P, Yoshii H, Okamoto S, Koike M, Gomi Y, Uchiyama Y, Takahashi M, Yamanishi K, Mori Y. Generation of a recombinant Oka varicella vaccine expressing mumps virus hemagglutinin-neuraminidase protein as a polyvalent live vaccine. Vaccine. 2007; 25:8741-8755. [PubMed: 18053621]

Sommer MH, Zagha E, Serrano OK, Ku CC, Zerboni L, Baiker A, Santos R, Spengler M, Lynch J, Grose C, Ruyechan W, Hay J, Arvin AM. Mutational analysis of the repeated open reading frames, ORFs 63 and 70 and ORFs 64 and 69, of varicella-zoster virus. J Virol. 2001; 75:82248239. [PubMed: 11483768]

Soong W, Schultz JC, Patera AC, Sommer MH, Cohen JI. Infection of human T lymphocytes with varicella-zoster virus: an analysis with viral mutants and clinical isolates. J Virol. 2000; 74:18641870. [PubMed: 10644359]

Strapans SI, Barry AP, Silvestri G, Safrit JT, Kozyr N, Sumpter B, Nguygen H, McClure H, Montefiori D, Cohen JI, Feinberg M. Enhance simian immunodeficiency virus replication and accelerated AIDS in macaques primed to mount a CD4 T cell response to SIV Env. Proc Natl Acad Sci. 2004; 101:13026-13031. [PubMed: 15326293]

Tischer BK, Kaufer BB, Sommer M, Wussow F, Arvin AM, Osterrieder N. A self-excisable infectious bacterial artificial chromosome clone of varicella-zoster virus allows analysis of the essential tegument protein encoded by ORF9. J Virol. 2007; 81:13200-13208. [PubMed: 17913822]

Visalli RJ, Fairhurst J, Srinivas S, Hu W, Feld B, DiGrandi M, Curran K, Ross A, Bloom JD, van Zeijl M, Jones TR, O'Connell J, Cohen JI. Identification of small molecule compounds that selectively inhibit varicella-zoster virus replication. J Virol. 2003; 77:2349-2358. [PubMed: 12551972] 
Xia D, Srinivas S, Sato H, Pesnicak L, Straus SE, Cohen JI. Varicella-zoster virus ORF21, which is expressed during latency, is essential for virus replication but dispensable for establishment of latency. J Virol. 2003; 77:1211-1218. [PubMed: 12502838]

Yamagishi Y, Sadaoka T, Yoshii H, Somboonthum P, Imazawa T, Nagaike K, Ozono K, Yamanishi $\mathrm{K}$, Mori Y. Varicella-zoster virus glycoprotein M homolog is glycosylated, is expressed on the viral envelope, and functions in virus cell-to-cell spread. J Virol. 2008; 82:795-804. [PubMed: 17977964]

Yoshii H, Sadaoka K, Matsuura M, Nagaike K, Takahashi M, Yamanishi K, Mori Y. Varicella-zoster virus ORF 58 gene is dispensable for viral replication in cell culture. Virol J. 2008; 30:5-54.

Yoshii H, Somboonthum P, Takahashi M, Yamanishi K, Mori Y. Cloning of full length genome of varicella-zoster virus vaccine strain into a bacterial artificial chromosome and reconstitution of infectious virus. Vaccine. 2007; 25:5006-5012. [PubMed: 17540483]

Zerboni L, Hinchliffe S, Sommer MH, Ito H, Besser J, Stamatis S, Cheng J, Distefano D, Kraiouchkine N, Shaw A, Arvin AM. Analysis of varicella zoster virus attenuation by evaluation of chimeric parent Oka/vaccine Oka recombinant viruses in skin xenografts in the SCIDhu mouse model. Virology. 2005; 332:337-346. [PubMed: 15661165]

Zerboni L, Sommer M, Ware CF, Arvin AM. Varicella-zoster virus infection of a human CD4-positive T-cell line. Virology. 2000; 270:278-285. [PubMed: 10792986]

Zhang Z, Rowe J, Wang W, Sommer M, Arvin A, Moffat J, Zhu H. Genetic analysis of varicellazoster virus ORF0 to ORF4 by use of a novel luciferase bacterial artificial chromosome system. J Virol. 2007; 81:9024-9033. [PubMed: 17581997] 


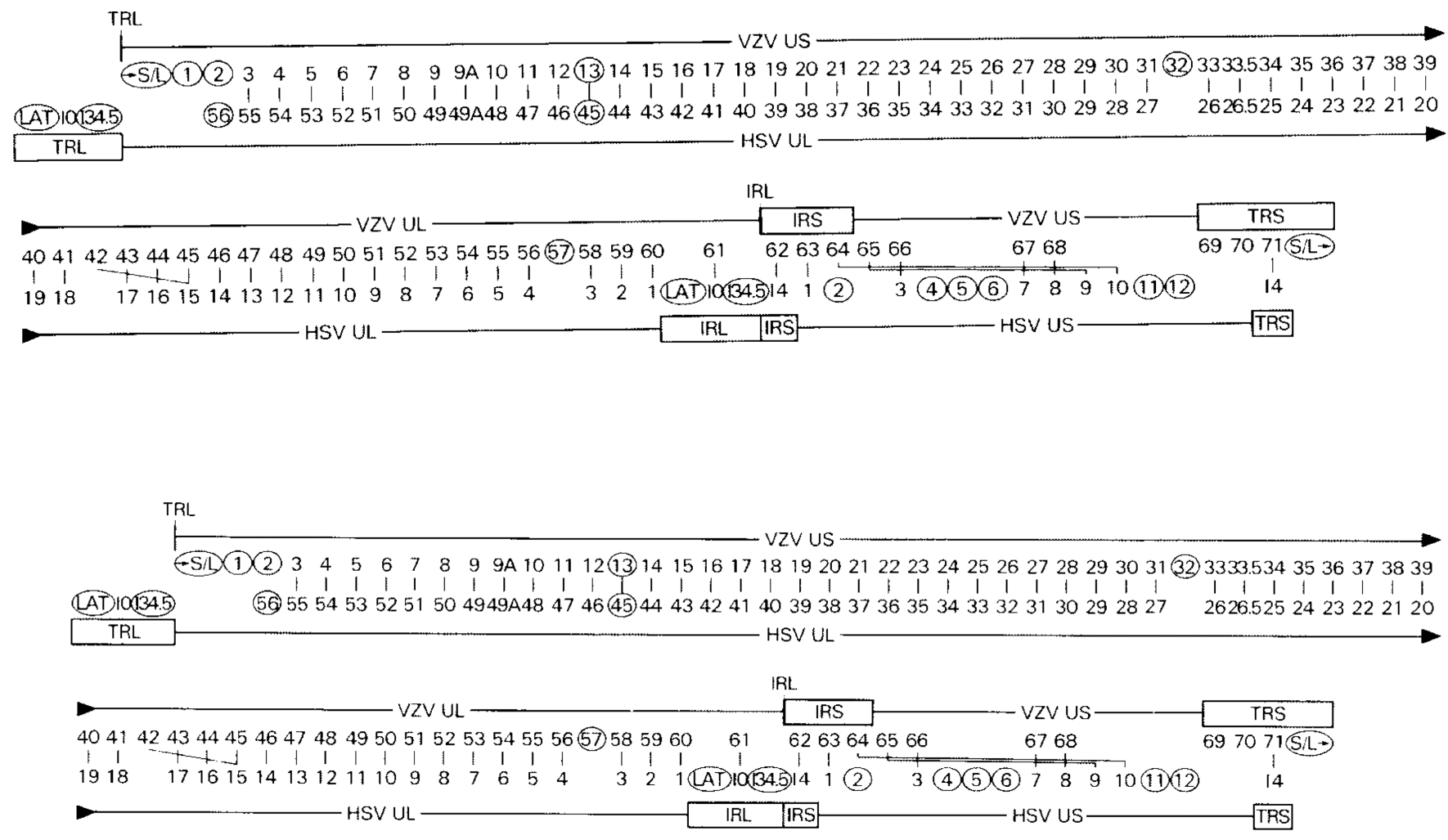

Figure 1.

Comparison of the VZV and HSV genomes. The VZV genome (first rows) contains unique long (UL) and unique short (US) regions flanked by terminal long (TRL), terminal short (TRS), internal long (IRL), and internal short (IRS) repeats. VZV genes (second rows) and HSV genes (third rows) are shown by numbers. VZV or HSV genes that do not have homologs in the corresponding virus circled. The HSV genome contains UL and US regions, and TRL, TRS, IRL, and IRS repeats (fourth rows). Modified from Cohen 1999, with permission. 
Table 1

VZV gene products

\begin{tabular}{|c|c|c|}
\hline $\begin{array}{l}\text { VZV } \\
\text { gene }\end{array}$ & HSV-1 homolog & VZV protein function \\
\hline 1 & None & Membrane protein \\
\hline 2 & None & \\
\hline 3 & UL55 & \\
\hline 4 & UL54 (ICP 27) & Transactivator, tegument protein, expressed in latency \\
\hline 5 & UL53 (gK) & $\mathrm{gK}$ \\
\hline 6 & UL52 (HPC) & \\
\hline 7 & UL51 & \\
\hline 8 & UL50 & Deoxyuridine triphosphatase \\
\hline 9 & UL49 (VP22) & Tegument protein \\
\hline $9 \mathrm{~A}$ & UL49A & Syncytia formation, putative $\mathrm{gN}$ \\
\hline 10 & UL48 (VP16) & Transactivator, tegument protein \\
\hline 11 & UL47 (VP13/14) & \\
\hline 12 & UL46 (VP11/12) & \\
\hline 13 & None & Thymidylate synthetase \\
\hline 14 & $\mathrm{UL} 44(\mathrm{gC})$ & $\mathrm{gC}$ \\
\hline 15 & UL43 & \\
\hline 16 & UL42 (PPF) & Putative small subunit of viral DNA polymerase \\
\hline 17 & UL41 (vhs) & Induces RNA cleavage \\
\hline 18 & UL40 & Ribonucleotide reductase, small subunit \\
\hline 19 & UL39 & Ribonucleotide reductase, large subunit \\
\hline 20 & UL38 (VP19C) & \\
\hline 21 & UL37 & Nucleocapsid protein, expressed in latency \\
\hline 22 & UL36 & \\
\hline 23 & UL35 (VP26) & Capsid assembly \\
\hline 24 & UL34 & \\
\hline 25 & UL33 & \\
\hline 26 & UL32 & \\
\hline 27 & UL31 & \\
\hline 28 & UL30 & DNA polymerase \\
\hline 29 & UL29 (ICP8) & ssDNA binding protein, expressed in latency \\
\hline 30 & UL28 & \\
\hline 31 & $\mathrm{UL} 27(\mathrm{gB})$ & $\mathrm{gB}$ \\
\hline 32 & None & Probable substrate for ORF47 kinase \\
\hline 33 & UL26 (VP24) & Protease \\
\hline 33.5 & UL26.5 (VP22) & Assembly protein \\
\hline 34 & UL25 & \\
\hline 35 & UL24 & Cell-to-cell fusion \\
\hline 36 & UL23 & Thymidine kinase \\
\hline 37 & UL22 (gH) & $\mathrm{gH}$ \\
\hline
\end{tabular}

Curr Top Microbiol Immunol. Author manuscript; available in PMC 2012 August 07. 


\begin{tabular}{|c|c|c|}
\hline $\begin{array}{l}\text { VZV } \\
\text { gene }\end{array}$ & HSV-1 homolog & VZV protein function \\
\hline 38 & UL21 & \\
\hline 39 & UL20 & \\
\hline 40 & UL19 (VP5) & Major nucleocapsid protein \\
\hline 41 & UL18 (VP23) & \\
\hline $42 / 45$ & UL15 & \\
\hline 43 & UL17 & \\
\hline 44 & UL16 & \\
\hline 46 & UL14 & \\
\hline 47 & UL13 & Protein kinase, tegument protein \\
\hline 48 & UL12 & Putative DNase \\
\hline 49 & UL11 & Virion protein \\
\hline 50 & $\mathrm{UL10}(\mathrm{gM})$ & $\mathrm{gM}$ \\
\hline 51 & UL9 & Origin binding protein \\
\hline 52 & UL8 (HPC) & \\
\hline 53 & UL7 & \\
\hline 54 & UL6 & Putative portal protein \\
\hline 55 & UL5 (HPC) & \\
\hline 56 & UL4 & \\
\hline 57 & None & Cytoplasmic protein \\
\hline 58 & UL3 & \\
\hline 59 & UL2 & Uracil-DNA glycosylase \\
\hline 60 & $\mathrm{UL1}(\mathrm{gL})$ & $\mathrm{gL}$, chaperone for $\mathrm{gH}$ \\
\hline 61 & ICP0 & Transactivator, transrepressor \\
\hline 62,71 & ICP4 & Transactivator, tegument protein, expressed in latency \\
\hline 63,70 & US1 (ICP22) & Tegument protein, transrepressor, inhibits interferon- alpha, expressed in latency \\
\hline 64,69 & US10 & \\
\hline 65 & US9 & Virion protein \\
\hline 66 & US3 & Protein kinase, expressed in latency \\
\hline 67 & US7 (gI) & gI \\
\hline 68 & US8 (gE) & $\mathrm{gE}$ \\
\hline $\mathrm{S} / \mathrm{L}$ & None & Cytoplasmic protein (also referred to as ORF0) \\
\hline
\end{tabular}

$\mathrm{HPC}=$ helicase-primase complex, $\mathrm{PPF}=$ polymerase processivity factor 
Table 2

Deletion and stop codon mutants constructed using cosmids or BACs in VZV and their effect on growth in vitro.

\begin{tabular}{|c|c|c|c|}
\hline VZV Gene & $\underline{\text { Mutation }}$ & $\underline{\text { Growth in Vitro }}$ & $\underline{\text { Reference }}$ \\
\hline ORFS/L (ORF0) & del & impaired & Zhang et al. 2007 \\
\hline \multirow[t]{2}{*}{ ORF1 } & stop & no change & Cohen and Seidel 1995 \\
\hline & del & slight reduced & Zhang et al. 2007 \\
\hline \multirow[t]{2}{*}{ ORF2 } & del & no change & Sato et al. 2002b \\
\hline & del & no change & Zhang et al. 2007 \\
\hline ORF3 & del & slight reduced & Zhang et al. 2007 \\
\hline \multirow[t]{3}{*}{ ORF4 } & del & essential & Cohen et al. 2005 \\
\hline & del & essential & Sato et al. $2003 \mathrm{~b}$ \\
\hline & del & essential & Zhang et al. 2007 \\
\hline ORF5 (gK) & del & essential & Mo et al. 1999 \\
\hline \multirow[t]{2}{*}{ ORF8 } & stop & no change & Ross et al. 2007 \\
\hline & delete $^{+}$ & reduced & Ross et al. 2007 \\
\hline \multirow[t]{2}{*}{ ORF9 } & start & essential & Tischer et al. 2007 \\
\hline & del & essential & Che et al. 2008 \\
\hline ORF9A & stop & no change & Ross et al. 1997 \\
\hline \multirow[t]{2}{*}{ ORF10 } & del & no change & Cohen and Seidel 1994b \\
\hline & del & no change & Che et al. 2008 \\
\hline ORF11 & del & no change & Che et al. 2008 \\
\hline ORF12 & del & no change & Che et al. 2008 \\
\hline ORF13 & stop & no change & Cohen and Seidel 1993 \\
\hline ORF14 (gC) & stop & no change & Cohen and Seidel 1994a \\
\hline ORF17 & del & reduced & Sato et al. 2002a \\
\hline ORF19 & del & reduced & Heineman and Cohen 1994 \\
\hline ORF21 & del & essential & Xia et al. 2003 \\
\hline ORF23 & del & reduced & Chaudhuri et al. 2008 \\
\hline ORF29 & del & essential & Cohen et al. 2007 \\
\hline ORF32 & del & no change & Reddy et al. 1998a \\
\hline ORF35 & del & reduced & Ito et al. 2005 \\
\hline ORF47 & stop & no change & Heineman and Cohen 1995 \\
\hline ORF49 & del & reduced & Sadaoka et al. 2007 \\
\hline ORF50 & del & reduced & Yamagishi et al. 2008 \\
\hline ORF57 & del & no change & Cox et al. 1998 \\
\hline ORF58 & del & no change & Yoshii et al. 2008 \\
\hline ORF59 & del & no change & Reddy et al. 1998b \\
\hline ORF61 & del & reduced & Cohen and Nguyen 1998 \\
\hline ORF62 & del & essential & Sato et al. 2003a \\
\hline \multirow[t]{2}{*}{ ORF63 } & del & essential & Sommer et al. 2001 \\
\hline & del & reduced & Cohen et al. 2004 \\
\hline
\end{tabular}

Curr Top Microbiol Immunol. Author manuscript; available in PMC 2012 August 07. 


\begin{tabular}{|c|c|c|c|}
\hline VZV Gene & Mutation & Growth in Vitro & Reference \\
\hline \multirow[t]{2}{*}{ ORF65 } & del & no change & Cohen et al. 2001 \\
\hline & del & no change & Niizuma et al. 2003 \\
\hline ORF66 & stop & no change & Heineman et al. 1996 \\
\hline \multirow[t]{2}{*}{ ORF67 (gI) } & del & reduced ${ }^{*}$ or essential & Cohen and Nguyen 1997 \\
\hline & del & reduced & Mallory et al. 1997 \\
\hline \multirow[t]{2}{*}{ ORF68 (gE) } & del & essential & Mallory et al. 1997 \\
\hline & del & essential & Ali et al. 2009 \\
\hline & \multicolumn{2}{|c|}{${ }^{+}$interrupts expression of ORF8 and ORF9A } & \\
\hline
\end{tabular}


Table 3

Recombinant VZV expressing other viral proteins

\begin{tabular}{lll}
\hline Viral protein & Immunogenicity & \multicolumn{1}{c}{ Reference } \\
EBV gp350 & Not reported & Lowe et al. 1987 \\
Hepatitis B SAg & Induced antibody to Hepatitis B S Ag & Shiraki et al. 1991 \\
HIV env & Induced humoral and cellular immunity to HIV & Shiraki et al. 2001 \\
SIV gp160 & Induced neutralizing antibody & Strapans et al. 2004 \\
& Enhanced SIV infection in monkeys & \\
HSV gD & $\begin{array}{l}\text { Induced neutralizing antibody to HSV-2 } \\
\text { Reduced severity of HSV-2 in guinea pigs }\end{array}$ & Heineman et al. 1995 \\
Mumps HA-N & Induced neutralizing antibody to mumps & Somboonthum et al. 2007 \\
HSV gD and gB & Induced neutralizing antibody to HSV-2 & Heineman et al. 2004 \\
\hline
\end{tabular}

gp350=glycoprotein 350, SAg=surface antigen, $\mathrm{gD}=$ glycoprotein $\mathrm{Dm}$ HA-N=hemagglutinin-neuraminidase, $\mathrm{gB}=\mathrm{glycoprotein} \mathrm{B}$ 